\title{
Characteristics of Liparis loeselii (L.) Rich. populations in selected Natura 2000 areas in eastern Poland
}

\author{
Danuta Urban $(\mathbb{D} \cdot$ Joanna Sender $\mathbb{D} \cdot$ \\ Ewelina Tokarz $\mathbb{D} \cdot$ Andrzej Różycki
}

Received: 12 July 2019/Revised: 13 May 2020 /Accepted: 11 July 2020 / Published online: 2 September 2020

(C) The Author(s) 2020

\begin{abstract}
In view of the sensitivity of Liparis loeselii to changes in habitat conditions, we carried out a study with the aim to monitor population numbers, identify the individual features of the Liparis loeselii population, analyse habitat conditions, identify threats and propose conservation measures to preserve the species. The investigations were conducted in seven unmanaged objects located in three Natura 2000 areas in eastern Poland. The results of this study provide a new insight into Liparis loeselii ecology. The analysed populations inhabited some habitat types: extremely poor fen, transitional mire, rich fen, calcareous fen, spring-fed fen. The content of nutrients was similar in all the habitats. A
\end{abstract}

\section{Urban · E. Tokarz}

Instytute of Soil Science and Environmental Engineering and Management, Department of Biological Bases of Forestry, University of Life Sciences in Lublin, Leszczyńskiego 7,

20-069 Lublin, Poland

D. Urban

e-mail: danuta.urban@up.lublin.pl

E. Tokarz

e-mail: talar.ewelina@gmail.com

J. Sender $(\bowtie)$

Department of Hydrobiology and Protection of Ecosystems, University of Life Sciences in Lublin, Dobrzańskiego 37 Street, 20-212 Lublin, Poland

e-mail: joanna.sender@up.lublin.pl

\section{A. Różycki}

Polesie National Park, Lubelska 3a, 22-234 Urszulin, Poland e-mail: andrzej.rozycki@ poleskipn.pl
$\mathrm{CCA}$ analysis revealed that the total carbon content, $\mathrm{pH}$, and redox potential of the substrate determine differences between the habitats analysed. Juvenile individuals represented a maximum of $12 \%$ of the analysed populations and were the least abundant group of these plants. The flowering was primarily influenced by hydrological conditions. Based on the long-term observations reported in this article, it can be assumed that the species stands a chance of surviving at the localities analysed, provided that the habitat conditions do not change dramatically.

Keywords biometric traits $\cdot$ Liparis loeselii $\cdot$ protected areas $\cdot$ flowering $\cdot$ threats $\cdot$ mires

\section{Introduction}

Liparis loeselii (L.) Rich. (fen orchid) is one of Poland's rarest plant species, which is why it is subject to strict species protection and requires active conservation. As specified in the Polish Red Data Book of Plants (Kaźmierczakowa and Zarzycki, 2014), the species is assigned category VU (vulnerable species threatened with extinction) and is under strict legal protection with an indication for active conservation (Regulation of the Minister of the Environment of 5, 2014). Liparis loeselii is also protected under the Berne Convention and Habitats Directive. It is a small, 5- to 20-cm high green or yellowish-green perennial (bulbous geophyte). It usually has two (seldom three) opposite, broadly lanceolate or spatulate leaves. The 5 - to 20 -cm long stem arises from a 
pseudo-bulb. The inflorescence contains from 1 to 18 yellowish-white flowers (Szlachetko 2009). Liparis loeselii occurs in North America and Eurasia. Its geographic range covers central and central-eastern Europe and the eastern regions of the USA (McMaster 2001). The species forms islets in the central and western parts of the USA and in Canada. In Europe it grows in Austria, Belgium, Bulgaria, Czechia, France, Germany, the Netherlands, Poland, Switzerland, Romania, Russia, Hungary, Italy, Bosnia and Herzegovina, Slovenia, Norway, and Finland (Baumann et al. 2010, Bzdon and Ciosek 2006, Fardeeva and Shafigullina 2013, Jacquemyn et al. 2005, Jarzombkowski and Pawlikowski 2012, Kucharski 2010, Kooijman et al. 2016, Milanović 2012, Pawlikowski et al. 2013, Szlachetko 2009, Wheeler et al. 1998).

Given its rare occurrence, the species has a status of a critically endangered orchidaceous plant in Poland (Kaźmierczakowa and Zarzycki 2014, Wołejko et al. 2019). Its localities have typically been reported from the north of Poland (Kucharski 2014, Szlachetko 2009, Zajacc and Zając 2001). Liparis loeselii is also scattered across the Central Polish Lowlands, in the Polesie region, and across the Uplands (Błońska et al. 2016, Fijałkowski and Izdebski 2002, Kucharski 2010, Pisarczyk 2006, Piwowarski and Przemyski 2012, Szlachetko 2009).

In the last few decades, new Liparis loeselii sites have been found in this region in the Zamość area (Michalczuk and Stachyra 2003), the Lublin Upland [http://natura2000.gdos.gov.pl/wyszukiwarka-n2k; Urban 1999, 2004, 2009, 2013b) and the LęczyńskoWłodawskie Lake District (Urban 2007a, b, 2013a).

Liparis loeselii occurs on groundwater-fed fens, carbonate soils and acidic-spring-fed fens maintained by mineral-poor groundwater, as well as on transitional mires (Jarzombkowski and Pawlikowski 2012, Kucharski 2010, Pillon et al. 2007). The species is mainly associated with phytocoenoses from the class Scheuchzerio-Caricetea nigrae. Most frequently it grows in communities from the order Caricetalia davallianae and sometimes in moss-covered reed associations from the class Phragmitetea. It is less frequently found in patches of the community Cladium mariscus (Megre et al. 2018) and on intermittently wet meadows from the alliance Molinion. It also grows in transitional mire communities and acidic mire communities of the order Scheuchzerietalia palustris (Błońska et al 2016, Jarzombkowski and Pawlikowski 2012, Kucharski
2010) and less frequently in phytocoenoses resembling communities from the class Oxycocco-Sphagnetea (Łachacz and Olesiński 2000). The species has been reported from many anthropogenic localities, for example gravel and sand post-excavation pits (Bzdon and Ciosek 2006, Czylok et al. 2008, Molenda 2004, Urban 2009). Liparis loeselii is a pioneer species which grows in the first stage of succession in wet habitats characterized by a variable water table (Roze et al. 2014, Megre et al. 2018).

Liparis loeselii, Liparis loeselii sites in Poland and thus have an impact on the loss of biodiversity. The decline in the population of this species is mainly caused by changes in the quality of habitats brought about by disturbances in water conditions, succession towards scrub- and woody-plant-dominated mires, encroachment of rush species (especially Phragmites australis), changes in mire trophy, and animal pressure (Jarzombkowski and Pawlikowski 2012, McMaster 2001, Wheeler et al. 1998, Naczk and Minasiewicz 2010, Pawlikowski 2004).

In view of the plant's sensitivity to changes in habitat conditions, we carried out a study with the aim to monitor population numbers, identify the individual features of the Liparis loeselii population, analyse habitat conditions, identify threats and propose conservation measures to preserve the species in habitats located in Natura 2000 areas. These areas differ from one another in their protection regime and form of ownership (Treasury and privately owned land), which may affect the possibility of implementing conservation measures for Liparis loeselii there. It should also be added that, for the most part, the investigated localities were new to the region.

\section{Material and methods}

\section{Study sites}

The study was conducted at seven Liparis loeselii sites (Fig. 1) located within three Natura 2000 areas. The sites were selected on the basis of the authors' previous research conducted in the years 20002013; they included localities that were new to the Lublin region, such as Komaszyce 1 and 2, Pawłów, Bagno Staw and Moszne 2 (Urban 2004, 2007a, b, 2013b), and previously known sites: Spławy and Moszne 1 (data from the Polesie National Park). 


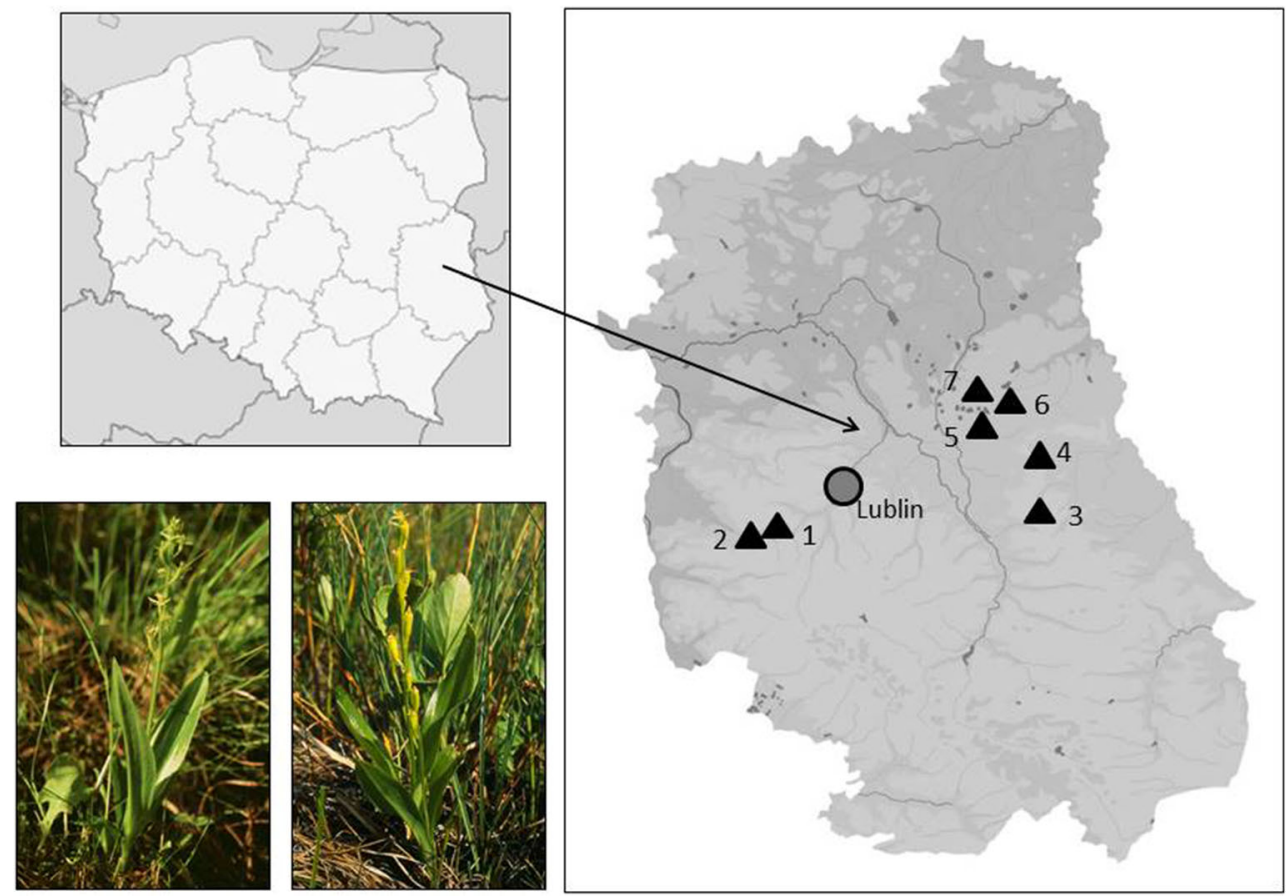

Fig. 1 Location of sites of Liparis loeselii analysed: 1 - Komaszyce 1, 2 - Komaszyce 2, 3 - Moszne 1, 4 - Moszne 2, 5 - Spławy, 6Bagno Staw, 7 - Pawłów.

In physical-geographical terms, the sites are located in the following macro-regions: Western Polesie (Moszne 1 and 2, Spławy, and Bagno Staw), Volhynian Polesie (Pawłów) and the Lublin Upland (Komaszyce 1 and 2, see Kondracki (2001). The climate of these macro-regions is transitional but has more features of continental climate compared to other regions of Poland. In Western Polesie the average temperature of the hottest month is around $18^{\circ} \mathrm{C}$ and the average temperature of the coldest month is around $-4^{\circ} \mathrm{C}$ (Kaszewski 2008). The distribution of water-dependent areas (hydrogenic habitats) in this region is typical of the whole of Polesie (Wilgat et al. 1991, Michalczyk et al. 2002). Because the groundwater table is shallow here, the landscape is dominated by vast wetland areas adjoining lakes. Total annual precipitation in Polesie does not exceed $575 \mathrm{~mm}$, and the vegetation period lasts 212 days. (Kaszewski 2008). In (the western part of) Volhynian Polesie the average temperature of the hottest month is around $17^{\circ} \mathrm{C}$ and the average temperature of the coldest month is around $-3^{\circ} \mathrm{C}$. The vegetation period lasts up to 212 days. Total annual precipitation is $550 \mathrm{~mm}$ (Kaszewski 2008). This region abounds in sandy and peaty plains located in depressions between hills. In the Lublin Upland (its western part), the average temperatures of the hottest and coldest months are around $17.6^{\circ} \mathrm{C}$ and $-3.2^{\circ} \mathrm{C}$, respectively. The vegetation period lasts up to 214 days. Total annual precipitation is $575 \mathrm{~mm}$ (Kaszewski 2008). According to Michalczyk and Wilgat (2008), the south-western part of the Lublin Upland is the region's low pressure trough; it is characterized by a dense network of water courses and the presence of valley mires.

Investigations of the local Liparis loeselii populations were carried out in the second half of July or the first half of August, depending on the flowering and fruiting peaks, in the years 2013-2015. The analyses were always performed at the same Liparis loeselii sites. No work was carried out in the Pawłów locality in 2013, and the Moszne 2 population was only discovered in 2014.

Data analysis

Phytosociological relevés were recorded using the Braun-Blanquet method (1964). The phytosociological 
classification and nomenclature of the plant communities were based on a paper by Matuszkiewicz (2008). The nomenclature of vascular plants was adopted from Mirek et al. (2002) and that of bryophytes followed Ochyra et al. (2003). Ecological mire types occurring on the tested objects are given according to Kotowski et al. (2017).

During Liparis loeselii flowering and fruiting periods, the water levels were measured and soil samples were taken at the investigated sites. In the years 20132015, in mid-July and mid-August, the water level from bedrock to water table was measured using piezometers (one piezometer per site). Also, climatic data, such as average air temperature and average precipitation at the study sites, were taken into account. The data were obtained from the weather service of the Polish Institute of Meteorology and Water Management - National Research Institute, IMGW-PIB (www.imgw.pl).

Soil was sampled (every year in mid-July) from a 0 $20 \mathrm{~cm}$ deep layer near the Liparis loeselii sites, and $\mathrm{pH}$ reaction, redox potential (Eh) and electrical conductivity (EC) were measured using the potentiometric method. Total carbon (TC), organic carbon (TOC) and inorganic carbon (IC) contents were determined with an SSM5000A module (Shimadzu, Japan) using a TOC-VCSH analyser. The contents of nitrogen $(\mathrm{N})$ and phosphorus (P) in mire extracts were measured using AA3 (Braun+ Luebbe, Germany). To determine the calcium (Ca) content, solid samples were mineralized and analysed using atomic absorption spectrometry with excitation in an acetylene-air flame. Means of soil analysis results for three consecutive years were used.

To characterize the age structure of the Liparis loeselii population, three morphological-developmental stages were distinguished: juvenile (with one leaf), vegetative (with two fully developed leaves) and generative (flowering individuals). Biometric measurements were carried out intravitally during the fieldwork in all Liparis loeselii individuals present at the localities analysed. The surface areas of these sites are given in Table 1. The following traits of the individual plants were analysed: height of the plant (HGT), length of the inflorescence (LIN), number of flowers (NFL), number of fruits (NFR), length of the longest leaf (LLL) and width of the longest leaf (WLL). The means and correlation coefficients $(P<0.05)$ were calculated using the Statistica 8.0 package. In addition, shading of Liparis loeselii sites was determined based on the degree of habitat overgrowth by woody, shrubby and herbaceous plants. A five-point scale of shading assessment of Liparis loeselii was used: 1 - no shading, 2 - weak (few herbaceous species on the surface with 1-25\% density), 3-moderate (herbaceous plants and shrubs, 26-50\% density), 4 - strong (herbaceous plants and shrubs, 51-75\% density), 5 - very strong (herbaceous plants and shrubs, 76-100\% density).

Pearson's correlation was used to determine the relationship between the number of Liparis loeselii individuals, climatic data and location. When the data did not have a normal distribution, they were normalized by $\log _{10}$. When the data could not be normalized, a nonparametric Spearman correlation test was used. Canonical correspondence analysis (CCA), using CANOCO for Windows 4.5 (Lepš and Šmilauer 2003), was performed to examine the correlation between species composition and environmental variables. Then, the marginal and conditional effects of each of the environmental variables on flora composition were examined. The effect of the first canonical axis was tested using a permutation test; the Monte Carlo test was carried out with 499 permutations (Ter Braak and Prentice, 1988; Ter Braak and Šmilauer, 2002; Piernik 2008).

\section{Results}

The floristic analyses revealed differences in habitat physiognomy. On the right side of the ordination diagram (Fig. 2) are species characteristic of extremely poor fen and transitional mires, for example Drosera rotundifolia, Sphagnum fallax, Oxycoccus palustris and Sphagnum cuspidatum (Moszne 1, 2 and Spławy). The middle of the diagram is occupied by populations dominated by species typical of areas with a neutral or alkaline $\mathrm{pH}$ reaction, for example Carex davalliana, Schoenus ferrugineus and Drepanocladus aduncus (Bagno Staw, Komaszyce 1, 2, Pawłów).

\section{Habitats}

Among the objects analysed, two groups of habitats were identified, associated with different types of mires. The first group consisted of the Moszne 1, Moszne 2, and Spławy sites, which are extremely poor fen and transitional mires. They were characterized by acidic reaction ( $\mathrm{pH}$ from 4.06 to 4.61 ), which had a redox potential indicative of the dominance of anaerobic processes, calcium content below $25.6 \mathrm{~g} \cdot \mathrm{kg}^{-1}$, and an 
Table 1 Characteristics of Liparis loeselii localities analysed

\begin{tabular}{|c|c|c|c|}
\hline $\begin{array}{l}\text { Locality / geographic } \\
\text { coordinates }\end{array}$ & $\begin{array}{l}\text { Surface area of } \\
\text { the locality }\left[\mathrm{m}^{2}\right]\end{array}$ & Communities & Form of protection \\
\hline $\begin{array}{l}\text { Komaszyce } 1 \\
\text { rich fen; old and overgrown } \\
\text { post-excavation pits } \\
51^{\circ} 06^{\prime} 50^{\prime \prime} \mathrm{N}, 22^{\circ} 05^{\prime} 02^{\prime \prime} \mathrm{E}\end{array}$ & 1,000 & $\begin{array}{l}\text { Caricetum acutiformis SAUER } 1937 \text {, } \\
\text { Caricetum appropinquatae (KOCH } \\
\text { 1926) SOÓ } 1938 \text {, } \\
\text { Caricetum rostratae RÜBEL } 1912 \text {, } \\
\text { Caricetum lasiocarpae KoCH } 1926 \text {, } \\
\text { assotiation Menanthes trifoliata }\end{array}$ & $\begin{array}{l}\text { Natura } 2000 \text { area Komaszyce PLH060063, } \\
\text { Chodel Protected Landscape Area }\end{array}$ \\
\hline $\begin{array}{l}\text { Komaszyce } 2 \\
\text { rich fen; old and } \\
\text { gyttja-filled } \\
\text { post-excavation pits } \\
51^{\circ} 07^{\prime} 18^{\prime \prime} \mathrm{N}, 22^{\circ} 04^{\prime} 15^{\prime \prime} \mathrm{E}\end{array}$ & 200 & $\begin{array}{l}\text { Phragmitetum australis (GAMS } \\
\text { 1927) SCHMALE 1939, Caricetum } \\
\text { acutiformis SAUER 1937, } \\
\text { Caricetum appropinquatae KoCH } \\
\text { 1926) SoÓ 1938, } \\
\text { Caricetum rostratae RÜBEL } 1912\end{array}$ & $\begin{array}{l}\text { Natura } 2000 \text { area Komaszyce PLH060063, } \\
\text { Chodel Protected Landscape Area }\end{array}$ \\
\hline $\begin{array}{l}\text { Moszne } 1 \\
\text { extremely poor fen } \\
51^{\circ} 27^{\prime} 38^{\prime \prime} \mathrm{N}, 23^{\circ} 06^{\prime} 59^{\prime \prime} \mathrm{E}\end{array}$ & 8 & $\begin{array}{l}\text { Sphagno-Caricetum rostratae } \\
\text { (STEFFEN 1931) SM. }\end{array}$ & $\begin{array}{l}\text { Natura } 2000 \text { area Ostoja Poleska } \\
\text { PLH060013, } \\
\text { Poleski National Park }\end{array}$ \\
\hline $\begin{array}{l}\text { Moszne } 2 \\
\text { extremely poor fen } \\
51^{\circ} 27^{\prime} 44^{\prime \prime} \mathrm{N}, 23^{\circ} 07^{\prime} 03^{\prime \prime} \mathrm{E}\end{array}$ & 44 & $\begin{array}{l}\text { Sphagno-Caricetum rostratae } \\
\text { (STEFFEN 1931) SM. }\end{array}$ & $\begin{array}{l}\text { Natura } 2000 \text { area Ostoja Poleska } \\
\text { PLH060013, } \\
\text { Poleski National Park }\end{array}$ \\
\hline $\begin{array}{l}\text { Spławy } \\
\text { transitional mire } \\
551^{\circ} 08^{\prime} 20^{\prime \prime} \mathrm{N}, 23^{\circ} 06^{\prime} 24^{\prime \prime} \mathrm{E}\end{array}$ & 59 & $\begin{array}{l}\text { Caricetum appropinquatae (КосH } \\
\text { 1926) Soó 1938, } \\
\text { Sphagno-Caricetum rostratae } \\
\text { (STEFFEN 1931) SM. } 1947\end{array}$ & $\begin{array}{l}\text { Natura } 2000 \text { area Ostoja Poleska } \\
\text { PLH060013, } \\
\text { Poleski National Park }\end{array}$ \\
\hline $\begin{array}{l}\text { Bagno Staw } \\
\text { calcareous fen/ } \\
51^{\circ} 20^{\prime} 10^{\prime \prime} \mathrm{N}, 22^{\circ} 19^{\prime} 54^{\prime \prime} \mathrm{E}\end{array}$ & 7 & $\begin{array}{l}\text { Caricetum davallianae DUTOIT } 1924 \\
\text { em. GÖRS 1963, } \\
\text { Caricetum acutiformis SAUER } 1937\end{array}$ & $\begin{array}{l}\text { Natura } 2000 \text { area Ostoja Poleska } \\
\text { PLH060013, } \\
\text { Poleski National Park }\end{array}$ \\
\hline $\begin{array}{l}\text { Pawłów } \\
\text { spring-fed fen/ } \\
51^{\circ} 08^{\prime} 25^{\prime \prime} \mathrm{N}, 23^{\circ} 13^{\prime} 58^{\prime \prime} \mathrm{E}\end{array}$ & 24 & $\begin{array}{l}\text { Caricetum lasiocarpae KoсH } 1926, \\
\text { Caricetum davallianae DuTOIT } 1924 \\
\text { em. Görs } 1963\end{array}$ & $\begin{array}{c}\text { Natura } 2000 \text { area Pawłów PLH060065, } \\
\text { Pawłów Protected Landscape Area }\end{array}$ \\
\hline
\end{tabular}

organic carbon content in the range of 42.4-55.8\%. The second group included the Komaszyce 1, Komaszyce 2, Bagno Staw and Pawłów - rich fen, calcareous fen and spring-fed fen (pH range of 6.48-6.94), the redox potential values in this group indicated the predominance of aerobic processes; the calcium content ranged from 92.5 to $116.2 \mathrm{~g} \cdot \mathrm{kg}^{-1}$, and the organic carbon content was in the range of $17.4-32.2 \%$. The content of nutrients (nitrogen and potassium) was similarly low in all the habitats.

CCA showed that the factors that had a large effect on the diversity of the habitats were total organic carbon content (TC), $\mathrm{pH}$ and the redox potential of soil; the first ordination axis explained as much as $57.3 \%$ of total variation. The second ordination axis, representing trophy indicators, explained $33.8 \%$ of the total variation (Fig. 2). The results of the statistical test are presented in Table 2.

\section{Hydrological conditions}

Fluctuations in groundwater level were observed at the localities analysed (Table 3). In 2013, Bagno Staw was the only locality at which the water table was below the mire surface (at a depth of $10 \mathrm{~cm}$ ). In 2014, a water table below the mire surface was observed in Pawłów and Bagno Staw (at a depth of 5-10 $\mathrm{cm}$ ), with water in the other localities persisting on the surface. Komaszyce 1 was the only site in which the groundwater level was above the mire surface $(5 \mathrm{~cm}$ on average). The year 2015 was the least favourable in terms of hydrology (piezometer readings 5-10 cm below the mire surface). Surface water was only observed in Moszne 1 and 2.

Probably, the fluctuations in groundwater level at the study sites were associated with the high average air 


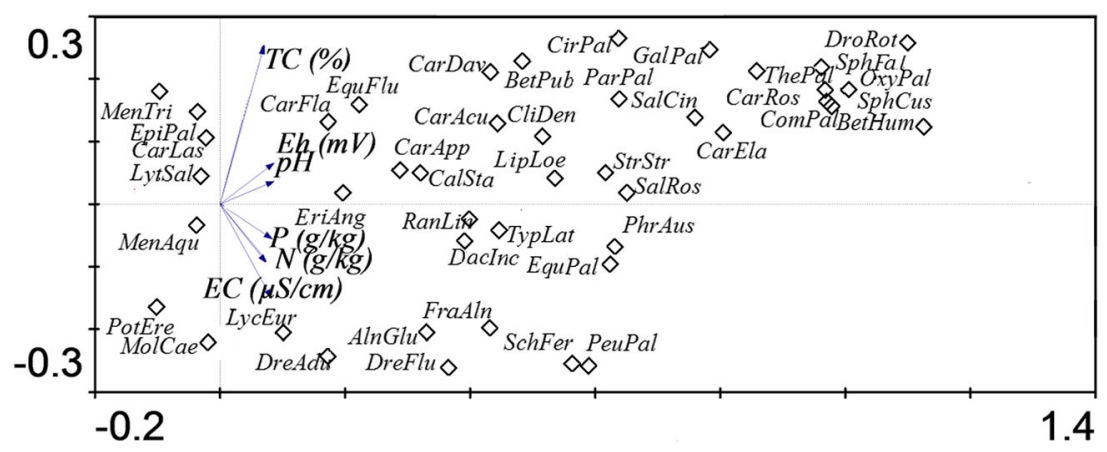

Fig. 2 Canonical Correspondence Analysis (CCA) diagram representing plant distribution depending on habitat parameters. AlnGlu - Alnus glutinosa, BetHum - Betula humilis, BetPub Betula pubescens, CalSta - Calliergon starmineum, CarAcu Carex acutiformis, CarApp - Carex appropinquata, CarDav Carex davalliana, CarEla - Carex elata, CarFla - Carex flava, CarLas - Carex lasiocarpa, CarRos - Carex rostrata, CirPal Cirsium palustre, CliDen - Climacium dendroides, ComPal Comarum palustre, DacInc - Dactylorhiza incarnata, DreAdu Drepanocladus aduncus, DreFlu - Drepanocladus fluitans. DroRot - Drosera rotundifolia, EpiPal - Epipactis palustris, EquFlu - Equisetum fluviatile, EquPal - Equisetum palustre,

temperature $\left(22^{\circ} \mathrm{C}\right)$ and low monthly precipitation, as indicated by the high correlation values (Table 4).

The number of individuals in all the populations was correlated positively $(R=0.84)$ with average monthly precipitation and weakly negatively correlated $(R=$ -0.27 ) with average monthly temperature (Table 4$)$.

Analysis of individual traits

The age structure of the populations in 2013 was dominated by generative individuals, which represented $53 \%$ of all investigated Liparis loeselii plants, whereas vegetative individuals dominated in 2014 and 2015 and

Table 2 Result of the Monte Carlo permutation test with 499 permutations for peat vegetation relative to environmental parameters

\begin{tabular}{lllll}
\hline Variable & Var. N & Lambda A & $P$ & $F$ \\
\hline TC & 7 & 0.36 & 0.001 & 9.05 \\
EC & 2 & 0.20 & 0.001 & 4.88 \\
$\mathrm{Eh}$ & 6 & 0.17 & 0.001 & 4.01 \\
$\mathrm{pH}$ & 4 & 0.10 & 0.001 & 3.99 \\
$\mathrm{P}$ & 5 & 0.05 & 0.302 & 1.44 \\
$\mathrm{~N}$ & 3 & 0.05 & 0.512 & 1.15 \\
$\mathrm{Ca}$ & 1 & 0.04 & 0.735 & 1.03 \\
\hline
\end{tabular}

EriAng - Eriophorum angustifolium, FraAln - Frangula alnus, GalPal - Galium palustre, LipLoe - Liparis loeselii, LycEur Lycopus europaeus, LysVul - Lysimachia vulgaris, LytSal Lythrum salicaria, MenAqu - Mentha aquatica, MenTri Menyanthes trifoliata, MolCae - Molinia caerulea, OxyPal Oxycoccus palustris, ParPal - Parnassia palustris, PeuPal Peucedanum palustre, PhrAus - Phragmites australis, PotEre Potentilla erecta, RanLin - Ranunculus lingua, SalCin - Salix cinerea, SalRos - Salix rosmarinifolia, SchFer - Schoenus ferrugineus, SphCus - Sphagnum cuspidatum, SphFal - Sphagnum fallax, StrStr - Straminergon stramineum, ThePal Thelypteris palustris, TypLat - Typha latifolia.

constituted $55 \%$ and $54 \%$ of the total population, respectively. Juvenile individuals were the least abundant and accounted for a maximum of $12 \%$ of the populations analysed. Flowering individuals dominated slightly $(55 \%)$ in 2013 whereas non-flowering plants constituted a majority in 2014 and $2015-67$ and $62 \%$, respectively (Table 5).

The morphological traits of the plants in the populations analysed varied across time and location (Table 6). The individuals usually had from two to four leaves, with most of them having two leaves. The average length of the largest leaf ranged from 1.2 to $22.0 \mathrm{~cm}$.

Table 3 Water levels (season average): '+' - above surface, '-' below surface; shading (\%): 1 - no shading, 2-weak (1-25\%), 3 moderate $(26-50 \%), 4$ - strong (51-75\%), 5 - very strong (76$100 \%)$ at the Liparis loeselii localities analysed, in 2013-2015; LD - lack of data

\begin{tabular}{lllllll}
\hline Locality & $\begin{array}{l}2013 \\
{[\mathrm{~cm}]}\end{array}$ & $\begin{array}{l}2014 \\
{[\mathrm{~cm}]}\end{array}$ & $\begin{array}{l}2015 \\
{[\mathrm{~cm}]}\end{array}$ & $\begin{array}{l}2013 \\
{[\%]}\end{array}$ & $\begin{array}{l}2014 \\
{[\%]}\end{array}$ & $\begin{array}{l}2015 \\
{[\%]}\end{array}$ \\
\hline Komaszyce 1 & 0 & +5 & -10 & 5 & 4 & 3 \\
Komaszyce 2 & 0 & 0 & -10 & 4 & 3 & 3 \\
Moszne 1 & 0 & 0 & 0 & 3 & 3 & 2 \\
Moszne 2 & 0 & 0 & 0 & LD & 3 & 3 \\
Spławy & 0 & 0 & -5 & 4 & 3 & 4 \\
Bagno Staw & -10 & -10 & -10 & 2 & 2 & 3 \\
Pawłów & 0 & -5 & -10 & LD & 4 & 4 \\
\hline
\end{tabular}


Table 4 Correlations between the precipitation rates, temperature and number of Liparis loeselii plants in 2013-2015 $(N=88$, linear, $R, *-P \leq 0.05 ; * *-P \leq 0.01 ; * * *-P \leq 0.001) ; \mathrm{WL}-$ water level

\begin{tabular}{llll}
\hline & $\begin{array}{l}\text { Temperature } \\
{\left[{ }^{\circ} \mathrm{C}\right]}\end{array}$ & $\begin{array}{l}\text { Precipitation } \\
{[\mathrm{mm}]}\end{array}$ & $\begin{array}{l}\mathrm{WL} \\
{[\mathrm{cm}]}\end{array}$ \\
\hline $\begin{array}{l}\text { Number of } \\
\text { individuals }\end{array}$ & $-0.27^{*}$ & $0.84 * * *$ & $0.72 * * *$ \\
$\begin{array}{l}\text { Temperature } \\
\text { Precipitation }\end{array}$ & & $-0.75^{* * * *}$ & $0.69 * * *$ \\
\hline
\end{tabular}

The average maximum and minimum width of the largest leaf in all the individuals analysed was 0.2 and 3.9 $\mathrm{cm}$, respectively. The average maximum stem height was $28.9 \mathrm{~cm}$ and the average minimum height was 2.4 $\mathrm{cm}$. The inflorescence was composed of a maximum of 18 flowers and a minimum of one flower; most frequently there were three flowers.

In the years 2013-2015, the largest mean number of flowering individuals (193) was noted at Komaszyce 1 and the lowest (23) at Bagno Staw. Non-flowering individuals predominated. This group was represented by 514 individuals in Spławy, which was also characterized by the occurrence of the tallest individuals (mean for the three years $=14.38 \mathrm{~cm}$ ) with the longest inflorescences $($ mean $=5.50 \mathrm{~cm}$ ) and the largest number of flowers $($ mean $=6.33)$ and fruits $($ mean $=3.98)$. In terms of the analysed biometric traits, the Moszne 1 population was outstanding, as it was characterized by the lowest values of these parameters (Table 6). Shady sites (especially Komaszyce 1, 2, Pawłów and Spławy) with more numerous trees, shrubs or herbaceous plants were characterized by the occurrence of Liparis loeselii individuals with longer leaves and the greatest number of flowers and fruits (Tables 3 and 6).

\section{Discussion}

Population size and flowering

The number of Liparis loeselii individuals in the localities analysed in 2013-2015 varied, ranging from several to several hundred individuals. The Spławy population exhibited the most stable high abundance, which may have been associated with the favourable hydrological and light conditions, as the individuals of this population inhabited exposed surfaces along a nature path (wooden bridge). The Moszne 1 and 2 populations also seemed to be stable in terms of abundance, although they were less numerous. A strong impact of weather conditions (water level, precipitation and temperature) on plant abundance was evident in the Bagno Staw population, which was the least numerous of all the seven populations studied. This is in line with the findings of McMaster (2001), who reports that the population size of Liparis loeselii depends on environmental conditions prevailing during the year as well as the pressure exerted by herbivores (mammals and insects).

Orchids are irregularly flowering plants. In so-called 'orchid years', massive flowering can be observed, whereas in other years there are substantially fewer flowering individuals (Tamm 1972). Wells et al. (1998) have found that weather conditions (precipitation, temperature) are the limiting factors. It is also known that plants prepare for flowering already at the beginning of the growing season or in the previous season (Leeson et al. 1991). Therefore, flowering is also determined by habitat conditions and the amount of energy stored by the plant. Kindlmann and Balounova (2001) mention additional factors, namely browsing by herbivores (mammals, insects) and the mode of management. Our investigations

Table 5 Age structure of the analysed Liparis loeselii populations in 2013-2015; LD - lack of data

\begin{tabular}{|c|c|c|c|c|c|c|c|c|}
\hline Year & Age structure & Komaszyce 1 & Komaszyce 2 & Moszne 1 & Moszne 2 & Spławy & Bagno Staw & Pawłów \\
\hline \multirow[t]{3}{*}{2013} & juvenile & 0 & 0 & 0 & $\mathrm{LD}$ & 29 & 1 & $\mathrm{LD}$ \\
\hline & vegetative & 0 & 0 & 33 & LD & 99 & 12 & $\mathrm{LD}$ \\
\hline & generative & 99 & 53 & 19 & LD & 25 & 4 & LD \\
\hline \multirow[t]{3}{*}{2014} & juvenile & 9 & 18 & 9 & 7 & 42 & 2 & 19 \\
\hline & vegetative & 62 & 133 & 57 & 11 & 164 & 9 & 48 \\
\hline & generative & 56 & 89 & 17 & 31 & 46 & 12 & 41 \\
\hline \multirow[t]{3}{*}{2015} & juvenile & 6 & 0 & 1 & 3 & 29 & 2 & 8 \\
\hline & vegetative & 34 & 28 & 43 & 13 & 151 & 3 & 34 \\
\hline & generative & 38 & 25 & 17 & 35 & 59 & 7 & 34 \\
\hline
\end{tabular}


Table 6 Biometric traits of Liparis loeselii plants at the localities analysed $(P<0.05)$

\begin{tabular}{|c|c|c|c|c|c|c|c|}
\hline \multicolumn{2}{|l|}{ Biometric trait } & \multirow{2}{*}{$\begin{array}{l}\text { HGT } \\
{[\mathrm{cm}]}\end{array}$} & \multirow{2}{*}{$\begin{array}{l}\text { LIN } \\
{[\mathrm{cm}]}\end{array}$} & \multirow{2}{*}{$\begin{array}{l}\text { NFL } \\
\text { [number] }\end{array}$} & \multirow{2}{*}{$\begin{array}{l}\text { NFR } \\
\text { [number] }\end{array}$} & \multirow{2}{*}{$\begin{array}{l}\text { LLL } \\
{[\mathrm{cm}]}\end{array}$} & \multirow{2}{*}{$\begin{array}{l}\text { WLL } \\
{[\mathrm{cm}]}\end{array}$} \\
\hline Locality & Year & & & & & & \\
\hline \multirow{3}{*}{$\begin{array}{l}\text { Komaszyce } 1 \\
\text { mean } \\
\min -\max \end{array}$} & 2013 & $\begin{array}{l}14.03 \\
7.024 .0\end{array}$ & $\begin{array}{l}4.21 \\
1.0-10.0\end{array}$ & $\begin{array}{l}4.28^{*} \\
1.0-11.0\end{array}$ & $\begin{array}{l}4.12 * \\
1.0-10.0\end{array}$ & $\begin{array}{l}10.68 * \\
4.6-19.0\end{array}$ & $\begin{array}{l}1.79 \\
0.5-3.0\end{array}$ \\
\hline & 2014 & $\begin{array}{l}14.41 \\
3.4-25.4\end{array}$ & $\begin{array}{l}3.96 \\
1.0-22.0\end{array}$ & $\begin{array}{l}2.56 \\
0-15.0\end{array}$ & $\begin{array}{l}1.19 \\
0-7.0\end{array}$ & $\begin{array}{l}8.38^{*} \\
3.4-19.3\end{array}$ & $\begin{array}{l}1.67 \\
0.7--2.6\end{array}$ \\
\hline & 2015 & $\begin{array}{l}15.81 * \\
9.0-25.6\end{array}$ & $\begin{array}{l}4.88 * \\
1.5-9.5\end{array}$ & $\begin{array}{l}2.99 \\
1.0-15.0\end{array}$ & $\begin{array}{l}2.40 \\
0-13.0\end{array}$ & $\begin{array}{l}8.93 * \\
1.2-17.2\end{array}$ & $\begin{array}{l}1.72 \\
0.5-1.6\end{array}$ \\
\hline \multirow{3}{*}{$\begin{array}{l}\text { Komaszyce } 2 \\
\text { mean } \\
\text { min-max }\end{array}$} & 2013 & $\begin{array}{l}12.48 \\
7.0-21.0\end{array}$ & $\begin{array}{l}4.04 \\
1.0-9.0\end{array}$ & $\begin{array}{l}4.68^{*} \\
1.0-14.0\end{array}$ & $\begin{array}{l}4.30^{*} \\
1.0-13.0\end{array}$ & $\begin{array}{l}8.58 * \\
4.0-15.0\end{array}$ & $\begin{array}{l}1.44 \\
0.7-2.5\end{array}$ \\
\hline & 2014 & $\begin{array}{l}12.86 \\
5.7-25.5\end{array}$ & $\begin{array}{l}3.97 \\
0.9-11.0\end{array}$ & $\begin{array}{l}2.15 \\
1.0-4.0\end{array}$ & $\begin{array}{l}0.92 \\
0-10.0\end{array}$ & $\begin{array}{l}7.40 \\
2.0-18.8\end{array}$ & $\begin{array}{l}1.57^{*} \\
0.5-2.8\end{array}$ \\
\hline & 2015 & $\begin{array}{l}14.16^{*} \\
9.6-23.3\end{array}$ & $\begin{array}{l}4.33 * \\
1.5-9.0\end{array}$ & $\begin{array}{l}3.06 \\
0-15.0\end{array}$ & $\begin{array}{l}1.62 \\
0-9.0\end{array}$ & $\begin{array}{l}7.68 \\
2.0-17.8\end{array}$ & $\begin{array}{l}1.33 \\
0.3-2.8\end{array}$ \\
\hline \multirow{3}{*}{$\begin{array}{l}\text { Moszne } 1 \\
\text { mean } \\
\text { min-max }\end{array}$} & 2013 & $\begin{array}{l}11.5^{*} \\
2.4-27.0\end{array}$ & $\begin{array}{l}3.06 \\
0.8-6.0\end{array}$ & $\begin{array}{l}1.15^{*} \\
1.0-9.0\end{array}$ & $\begin{array}{l}0.00 \\
0-0\end{array}$ & $\begin{array}{l}7.25 \\
1.0-15.5\end{array}$ & $\begin{array}{l}1.29 \\
0.2-2.4\end{array}$ \\
\hline & 2014 & $\begin{array}{l}11.96^{*} \\
6.3-17.7\end{array}$ & $\begin{array}{l}3.01 \\
0.7-5.2\end{array}$ & $\begin{array}{l}0.52 \\
1.0-8.0\end{array}$ & $\begin{array}{l}0.40 \\
0-6.0\end{array}$ & $\begin{array}{l}7.13 \\
1.8-20.0\end{array}$ & $\begin{array}{l}1.28 \\
0.7-2.5\end{array}$ \\
\hline & 2015 & $\begin{array}{l}12.21 * \\
8.6-20.0\end{array}$ & $\begin{array}{l}3.44 \\
0-10.4\end{array}$ & $\begin{array}{l}2.02 \\
0-11.0\end{array}$ & $\begin{array}{l}0.60 \\
0-6.0\end{array}$ & $\begin{array}{l}7.10 \\
1.8-12.5\end{array}$ & $\begin{array}{l}1.33 \\
0.2-2.2\end{array}$ \\
\hline \multirow{3}{*}{$\begin{array}{l}\text { Moszne } 2 \\
\text { mean } \\
\text { min-max }\end{array}$} & 2013 & LD & $\mathrm{LD}$ & $\mathrm{LD}$ & LD & LD & LD \\
\hline & 2014 & $\begin{array}{l}12.84 * \\
6.1-18.6\end{array}$ & $\begin{array}{l}3.33 \\
0.4-6.3\end{array}$ & $\begin{array}{l}1.86 \\
1.0-9.0\end{array}$ & $\begin{array}{l}0.84 \\
0-8.0\end{array}$ & $\begin{array}{l}8.53^{*} \\
2.0-16.0\end{array}$ & $\begin{array}{l}1.50 \\
0.5-2.5\end{array}$ \\
\hline & 2015 & $\begin{array}{l}14.96^{*} \\
8.7-22.0\end{array}$ & $\begin{array}{l}4.58 * \\
2.3-8.4\end{array}$ & $\begin{array}{l}2.37 \\
1.0-15.0\end{array}$ & $\begin{array}{l}1.29 \\
0-13.0\end{array}$ & $\begin{array}{l}7.68^{*} \\
1.3-15.7\end{array}$ & $\begin{array}{l}1.45 \\
0.2-9.0\end{array}$ \\
\hline \multirow{3}{*}{$\begin{array}{l}\text { Bagno Staw } \\
\text { mean } \\
\text { min-max }\end{array}$} & 2013 & $\begin{array}{l}11.27 \\
3.6-17.3\end{array}$ & $\begin{array}{l}4.38 * \\
3.1-6.4\end{array}$ & $\begin{array}{l}1.47^{*} \\
1.0-9.0\end{array}$ & $\begin{array}{l}1.47 \\
0-9.0\end{array}$ & $\begin{array}{l}7.75^{*} \\
2.5-11.3\end{array}$ & $\begin{array}{l}1.54 \\
0.6-2.2\end{array}$ \\
\hline & 2014 & $\begin{array}{l}10.48 * \\
4.2-15.2\end{array}$ & $\begin{array}{l}2.82 * \\
0-5.2\end{array}$ & $\begin{array}{l}2.45 \\
1.0-10\end{array}$ & $\begin{array}{l}0.58 \\
0-5.0\end{array}$ & $\begin{array}{l}7.16 \\
2.8-12.5\end{array}$ & $\begin{array}{l}1.42 \\
0.5-2.5\end{array}$ \\
\hline & 2015 & $\begin{array}{l}11.13 \\
7.8-13.6\end{array}$ & $\begin{array}{l}1.67 * \\
1.2-2.3\end{array}$ & $\begin{array}{l}2.83 \\
1.0-7.0\end{array}$ & $\begin{array}{l}0.83 \\
0-5.0\end{array}$ & $\begin{array}{l}7.92 * \\
3.1-17.5\end{array}$ & $\begin{array}{l}1.56 \\
0.5-3.7\end{array}$ \\
\hline \multirow{3}{*}{$\begin{array}{l}\text { Splawy } \\
\text { mean } \\
\text { min-max }\end{array}$} & 2013 & $\begin{array}{l}14.69 * \\
0-28.9\end{array}$ & $\begin{array}{l}4.42 \\
1.0-11.6\end{array}$ & $\begin{array}{l}6.91 * \\
1.0-18.0\end{array}$ & $\begin{array}{l}4.06 \\
1.0-12.0\end{array}$ & $\begin{array}{l}7.86^{*} \\
1.5-20.6\end{array}$ & $\begin{array}{l}1.34 \\
0.2-11.3\end{array}$ \\
\hline & 2014 & $\begin{array}{l}15.63 \\
9.3-23.9\end{array}$ & $\begin{array}{l}4.83 \\
1.7-16.0\end{array}$ & $\begin{array}{l}3.69 \\
1.0-14.0\end{array}$ & $\begin{array}{l}2.48 \\
0-11.0\end{array}$ & $\begin{array}{l}6.90^{*} \\
1.6-21.6\end{array}$ & $\begin{array}{l}1.53 * \\
0.4-3.5\end{array}$ \\
\hline & 2015 & $\begin{array}{l}15.73 \\
3.8-24.7\end{array}$ & $\begin{array}{l}7.05^{*} \\
1.5-27.4\end{array}$ & $\begin{array}{l}4.85 \\
1.0-15.0\end{array}$ & $\begin{array}{l}3.54 \\
0-11.0\end{array}$ & $\begin{array}{l}8.68^{*} \\
3.4-22.0\end{array}$ & $\begin{array}{l}1.34 \\
0.4-3.5\end{array}$ \\
\hline \multirow{3}{*}{$\begin{array}{l}\text { Pawłów } \\
\text { mean } \\
\text { min-max }\end{array}$} & 2013 & LD & LD & LD & LD & LD & $\mathrm{LD}$ \\
\hline & 2014 & $\begin{array}{l}14.92 \\
8.6-25.7\end{array}$ & $\begin{array}{l}3.77 \\
1.3-8.3\end{array}$ & $\begin{array}{l}3.76^{*} \\
1.0-9.0\end{array}$ & $\begin{array}{l}3.51 \\
0-9.0\end{array}$ & $\begin{array}{l}9.10^{*} \\
2.0-19.2\end{array}$ & $\begin{array}{l}1.87 * \\
0.9-3.9\end{array}$ \\
\hline & 2015 & $\begin{array}{l}13.91 \\
7.5-26.5\end{array}$ & $\begin{array}{l}4.28 \\
1.5-11.0\end{array}$ & $\begin{array}{l}6.59 * \\
3.0-15.0\end{array}$ & $\begin{array}{l}3.85 \\
0-11.0\end{array}$ & $\begin{array}{l}7.65^{*} \\
2.0-20.0\end{array}$ & $\begin{array}{l}1.47^{*} \\
0.4-3.3\end{array}$ \\
\hline
\end{tabular}

HGT - height of the plant, LIN - length of the inflorescence, NFL - number of flowers, NFR - number of fruits, LLL - length of the longest leaf, WLL - width of the longest leaf

indicate that hydrological conditions have a major impact on the flowering of the analysed species. In the Komaszyce 2 population, the number of flowering individuals declined by $60 \%$ after the water level had decreased in this locality. A negative effect of an increase in the water level $(5 \mathrm{~cm}$ above the mire surface) was noted in the north-western part of the Komaszyce 1 site. It has been demonstrated that even short periods in which 
the water table declines or rises may inhibit flowering, resulting in the presence of plants in the vegetative stage only (Jersakova and Kinndlman 2004).

Habitat

The present investigations show that the environmental parameters measured in the study, describing the habitat of Liparis loeselii (TC, pH, Eh, EC, P, N, Ca), explain a large proportion of population variability $(57.3 \%)$. The other part of the variability can be explained by the water level, weather conditions, availability of light, mode of management, impact of herbivores and the biology of the species, that is, its ephemeral nature. Similar relationships have been observed by other authors (McMaster 2001; Roze et al. 2014).

The CCA analysis distinguished two groups in the investigated populations. The first group preferred acidic habitats and the second alkaline ones. The former was more abundant and was characterized by the presence of taller individuals producing a greater number of flowers and fruits in comparison with the latter. Voss (1972) reported the presence of taller individuals with a greater number of flowers in wet habitats and shorter plants in drier habitats. This author also reported that plants growing in exposed sites had leaf lengths of up to $22 \mathrm{~cm}$ whereas plants which inhabited shaded areas had longer leaves up to $30 \mathrm{~cm}$ long (Voss 1972). Our investigations confirm this dependence, as the tallest individuals with the greatest number of flowers and fruits were found in shaded sites.

Threats and conservation measures

The existing threats to the investigated sites of Liparis loeselii include disturbances of hydrological conditions (both lowering of the water level and flooding of mires), as well as succession of scrub communities and encroachment of herbaceous and rush species caused by the abandonment of cutting on meadows. No agricultural activity was observed in the habitats analysed.

The investigated populations of Liparis loeselii are threatened or potentially threatened by wild boar rooting. This especially concerns plants growing on fens (Komaszyce 1 and 2, Pawłów, Bagno Staw) under low water level conditions. When the soil has a high moisture content, the places where soil has been rooted and exposed become a potential habitat for this species.
Extremely poor fen sites (Moszne 1) are threatened by beavers. These animals destroy habitats of Liparis loeselii by digging channels on their edges to facilitate transport of felled tree branches. At the same time, the surroundings of these channels (exposed surfaces without Sphagnum spp. and other species) can be potential germination sites for Liparis loeselii. This is confirmed by Rolfsmeier (cited by Jarzombkowski and Pawlikowski 2012), who also believes that the fen orchid is threatened by the disappearance of germination sites even in places with good hydrological conditions where appropriate fungi are growing (Illyés 2003).

In addition, changes in climatic conditions that affect the hydrological conditions of mires are an important present and potential threat to the population of Liparis loeselii. The effects of these changes were particularly prominent during the very dry and warm summer of 2015 in the case of the populations of Komaszyce 1 and 2. At that time, the population of Liparis loeselii was reduced by almost half compared to the previous year. Therefore, extremely poor fen and transitional mires are more suitable for occurring of Liparis loeselii populations because the water levels are more stable. Other potential threats include peat extraction and pond digging as well as afforestation of areas of occurrence of the species or their vicinity (Komaszyce 1 and 2, Pawłow).

To preserve and protect this species, measures should be taken to maintain natural succession and favourable water conditions in the orchid's habitats. Succession (Błońska et al. 2016) in the analysed localities can be prevented by eliminating tree and shrub (Salix sp., Betula sp.) undergrowth, mowing Phragmithes australis, and removing dead organic matter and biomass outside the habitat to improve the light conditions and promote the dispersal of Liparis loeselii seeds. These activities, which have been undertaken in some fen orchid sites in the Polesie National Park, have been reported to bring positive results. Therefore, it seems reasonable to implement this strategy in the other localities. Taking into account the annual life cycle of the species, 'clearing' activities should be performed in February and March (Roze et al. 2014).

The limited water supply from the Liparis loeselii sites seems to be the most important mechanism determining the occurrence and flowering of this species. Water-upwelling through the construction of dams in the Polesie National Park is bringing measurable effects by creating stable hydrological conditions for Liparis loeselii despite the high air temperatures and low precipitation recorded in recent years. 
The size of Liparis loeselii populations depends on environmental conditions prevailing during the year as well as the pressure exerted by herbivores and invertebrates (McMaster 2001). In the populations investigated in this study, only a few cases of leaf or inflorescence damage, so-called bites, were noted.

All analysed populations of Liparis loeselii are located in Natura 2000 areas, but active conservation measures are implemented mainly in the Poleski National Park. For other areas, which are privately owned land, implementation of conservation measures is non-obligatory. Conservation can be accomplished through the purchase of land from the owners, providing financial support to them (an agri-environmental programme and other subsidies) and educational programmes.

The results of research are local, but they can be useful for the protection and preservation of this rare species in Poland.

Acknowledgements We wish to extend special thanks to Gerard Potakiewicz for his assistance in field studies. This work was supported by the National Science Centre of Poland's grant NN305410338 (D.U.).

Data accessibility The original data is stored in the Institute of Soil Science and Environmental Engineering and Management, Department of Biological Bases of Forestry, University of Life Sciences in Lublin, Leszczyńskiego 7, 20-069 Lublin, Poland.

Open Access This article is licensed under a Creative Commons Attribution 4.0 International License, which permits use, sharing, adaptation, distribution and reproduction in any medium or format, as long as you give appropriate credit to the original author(s) and the source, provide a link to the Creative Commons licence, and indicate if changes were made. The images or other third party material in this article are included in the article's Creative Commons licence, unless indicated otherwise in a credit line to the material. If material is not included in the article's Creative Commons licence and your intended use is not permitted by statutory regulation or exceeds the permitted use, you will need to obtain permission directly from the copyright holder. To view a copy of this licence, visit http://creativecommons.org/licenses/by/4.0/.

\section{References}

Baumann H, Künkele S, Lorenz R (2010) Storyczki Europy $i$ obszarów sasiednich [European orchids and neighbouring areas]. Multico Press [In Polish]

Błońska A, Halabowski D, Sowa A (2016) Population structure of Liparis loeselii (L.) Rich. in relation to habitat conditions in the Warta River valley (Poland). Biodivers Res Conservation $43: 41-52$
Braun-Blanquet J (1964) Pflanzensoziologie, Grundzüge der Vegetationskunde, 3. Aufl. Wien - New York, Springer, pp 865

Bzdon G, Ciosek MT (2006) Fen orchid Liparis loeselii (L.) Rich. in an abandoned gravel-pit in Dąbrówka Stany near Siedlce (Poland). Biodivers Res Conservation 1-2:193-195

Czylok A, Rahmonov O, Szymczyk A (2008) Biological diversity in the area of quarries after sand exploitation in the eastern part of Silesian Upland. Teka Komis Ochr Środow Przyr 5A:15-22

Fardeeva MB, Shafigullina NR (2013) Liparis loselii (L.) Rich. and Herminium monorchis (L.) R. Br. (Orchidaceae) in Tatarstan (Russia). Ecological characteristics and population structure. Sci Notes Kazan Univ 155:135-147

Fijałkowski D, Izdebski K (2002) Poleski Park Narodowy - flora naczyniowa.[Poleski National Park - vascular flora] In Radwan S (Ed). Poleski Park Narodowy - Monografia Przyrodnicza. Wydawnictwo Morpol, Lublin, pp 103-114 [In Polish]

Jacquemyn H, Brys R, Hermy M, Willems JH (2005) Does nectar reward affect rarity and extinction probabilities of orchid species? An assessment using historical records from Belgium and the Netherlands. Biol Conservation 121:257-263

Jarzombkowski F, Pawlikowski P (2012) Krajowy program ochrony lipiennika Loesela Liparis loeselii (L.) Rich. [National protection programme for Liparis loeselii (L.) Rich.] Klub Przyrodników Press, Świebodzin, pp 1-26 [in Polish]

Jersakova J, Kinndlman P (2004) Reproductive success and sex variation in nectarless and rewarding orchids. Int $\mathrm{J} \mathrm{Pl} \mathrm{Sci}$ 165:779-785

Kaszewski B M (2008) Warunki klimatyczne Lubelszczyzny. Wydawnistwo UMCS, p 60 [In Polish]

Kaźmierczakowa R, Zarzycki K (2014) Polska czerwona księga roślin [Polish red book of plants]. The Władysław Szafer Institute of Botany of the Polish Academy of Sciences, Kraków, pp 664 [In Polish]

Kindlmann P, Balounova Z (2001) Irregular flowering patterns in terrestrial orchids. Theories vs empirical data. Web Ecol 2:75-82

Kondracki J (2001) Geografia regionalna Polski. Wyd. Naukowe PWN, Warszawa

Kooijman AM, Bruin CJW, van de Craats A, Grootjans AP, Oostermeijer JGB, Scholten R, Sharudin R (2016) Past and future of the EU-habitat directive species Liparis loeselii in relation to landscape and habitat dynamics in SW-Texel, the Netherlands. Sci Total Environm 568:107-117

Kotowski W, Dembek W, Pawlikowski P (2017) Country chapters. Poland. In Joosten H, Tanneberger F, Moen A (eds) Mires and peatlands of Europe. Status, distribution and conservation. Schweizerbart Scince Publishers. Stuttgart, pp 549-571

Kucharski L (2010) 1903 Liparis loeselii (L.) Rich. In Perzanowska J (ed.) Monitoring gatunków. Przewodnik metodyczny. GIOŚ, Warszawa, 99-109 [In Polish]

Łachacz A, Olesiński L (2000) Flora i roślinność torfowiska Jeziorko na Pojezierzu Mazurskim [Flora and vegetation of the 'Jeziorko' peatbog in the Masurian Lake District]. Fragm Florist Geobot Polon 7:129-143

Leeson E, Haynes C, Wells TCE (1991) Studies of the phenology and dry matter allocation of Dactylorhiza fuchsii. In Wells TCE, Willems JH (eds) Population ecology of terrestrial orchids. SPB Academic Publishing BV, The Hague, pp 125-138

Lepš J, Šmilauer P (2003) Multivariate analysis of ecological data using CANOCO. Cambridge University Press, Cambridge 
Llyés Z (2003) A Liparis loeselii aktiv védelmét célzó aszimbiotikus és szimbiotikus nevelése és szimbionta gombapartnereinek molekuláris azonositása. ELTE University. Budapest, Hungary Available at www.greenfo. hu/uploads/szakdolgozatok/Illyesteljes.pdf

Matuszkiewicz W (2008) Przewodnik do oznaczania zbiorowisk roślinnych Polski [Guide for the determination of plant communities Polish]. Publ. Naukowe PWN, pp 536 [In Polish]

McMaster RT (2001) The population biology of Liparis loeselii, Loesel's twayblade, in a Massachusetts wetland. $N E$ Naturalist 8:163-178

Megre D, Roze D, Dokane K, Jakobsone G, Karlovska A (2018) Survival of an endangered orchid Liparis loeselii in habitats with different water level fluctuations. Polish J Ecol 66:126-139

Michalczuk W, Stachyra P (2003) Nowe stanowiska lipiennika Loesela Liparis loeselii (L.) Rich. na Zamojszczyźnie [New positions of Liparis loeselii (L.) Rich. in the Zamość region] Chrońmy Przyr Ojczysta 59:122-125 [In Polish]

Michalczyk Z, Bartoszewski S,Turczyński M (2002) Stosunki wodne Polesia [Water relations in Polesie] [In] Radwan S. (Ed) Środowisko przyrodnicze Polesia - stan aktualny i zmiany. Acta Agrophysica 66: 49-76.

Michalczyk Z, Wilgat T (2008) Wody In Uziak S, Turski R (ed.) Środowisko przyrodnicze Lubelszczyzny. LTN, Lublin, pp 119-209

Milanović D (2012) Liparis loeselii (L.) Rich. - a plant rediscovered in the Balkan peninsula. Bot Serbica 36:85-89

Mirek Z, Piękoś-Mirkowa H, Zając A, Zając M (2002) Flowering plants and pteridophytes of Poland. A checklist. The W. Szafer Institute of Botany, Polish Academy of Sciences. Kraków, pp 442

Molenda T (2004) Antropogeniczne mokradła Wyżyny Ślaskiej [Anthropogenic wetlands of the Silesian Upland]. The Bogs, Mountains and Highlands Symposium. Kielce-Białe Ługi.: 34-35

Naczk A, Minasiewicz J (2010) Zróżnicowanie morfologiczne $i$ ekologiczne wybranych populacji Liparis loeselii (L.) LC Rich. (Orchidaceae) na Pomorzu Gdańskim [Morphological and ecological differentiation of selected populations of Liparis loeselii (L.) L. C. Rich. (Orchidaceae) in the Pomorze Gdañskie region]. Acta Bot Cassubica 7-9:147-160 [In Polish]

Ochyra R, Żarnowiec J, Bednarek-Ochyra H (2003) Census catalogue of Polish mosses. Polish Academy of Sciences, Institute of Botany, Kraków

Pawlikowski P, Abramczyk K, Szczepaniuk A (2013) Nitrogen: phosphorus ratio as the main ecological determinant of the differences in the species composition of brown-moss rich fens in north-eastern Poland. Preslia 85:349-367

Pawlikowski P Liparis loeselii (L.) Rich. Liparis Loesela. In Studnik-Wójcikowska B, Werblan-Jakubiec H (2004) Gatunki roślin. Poradniki ochrony siedlisk i gatunków Natura 2000 - podręcznik metodyczny 9. Ministerstwi Środowiska. Kraków, pp 150-154 [In Polish]

Piernik A (2008) Metody numeryczne w ekologii: na przyktadzie zastosowań pakietu MVSP do analiz roślinności. Wydawnictwo Naukowe Uniwersytetu Mikołaja Kopernika, Torun, pp 103

Pillon Y, Qamaruz-Zaman F, Fay MF, Hendoux F, Piquot Y (2007) Genetic diversity and ecological differentiation in the endangered fen orchid (Liparis loeselii). Conservation Genet 8:177-184
Pisarczyk E (2006) Nowe stanowisko stanowiska lipiennika Loesela Liparis loeselii (L.) Rich. na terenie Krakowa na tle rozmieszczenia gatunku w południowo-wschodniej Polsce [New position of the Liparis loeselii (L.) Rich. in Krakow on the background of species distribution in south-eastern Poland]. Chrońmy Przyr Ojczysta 62:50-54 [In Polish]

Piwowarski B, Przemyski A (2012) Occurrence of Liparis loeselii (L.) Rich. in the Małopolska Upland (South Poland). Bot Steciana 16:31-35

Regulation of the Minister of the Environment of 5 2014. On wild species of plants under protection. Off Law $J 81$

Roze D, Jakobsone G, Megre D, Belogrudova I, Karlovska A (2014) Survival of Liparis loeselii (L.) as an early successional species in Engure Region described based on ecological peculiarities during the annual cycle, Proc Latv Acad Sci B. $68: 93-100$

Szlachetko DL (2009) Flora Polski, Storczyki [Flora of Poland, Orchids]. Multico Oficyna Wydawnicza, pp 164-165 [In Polish]

Tamm CO (1972) Survival and flowering of some perennial herbs. II. The behavior of some orchids on permanent plots. Oikos 23:23-28

ter Braak CJF, Prentice IC (1988) A theory of gradient analysis. Advances Ecol Res 18:271-317

ter Braak CJF, Šmilauer P (2002) CANOCO reference manual and CanoDraw for Windows user's guide: software for canonical community ordination (version 4.5), Biometris, $500 \mathrm{pp}$

Urban D (1999) Szata roślinna małych torfowisk wybranych dolin rzecznych Wyżyny Lubelskiej [Vegetation of small bogs in selected river valleys of the Lublin Upland]. Fol Univ Agric Stein 197 Agricultura 75:339-344 [In Polish]

Urban D (2004) Siedliska hydrogeniczne oraz geneza i ewolucja wybranych torfowisk dolinowych Wyzyny Lubelskiej $i$ Wotyńskiej [Hydrogenic habitats and the genesis and evolution of selected valley bogs of the Lublin Upland and Wotyńska Uplands]. Akademia Rolnicza, Lublin, pp 1-144 [In Polish]

Urban D (2007b) Plant communities of peat pits and ponds in the area of Sobibór Forests (Lęczyńsko-Włodawskie Lakeland). Teka Komis Ochr Środow Przyr 4:285-292

Urban D (2009) Walory florystyczne i fitosocjologiczne wybranych piaskowni w województwie lubelskim [Floristic and phytosociological values of selected sandpits in Lublin province]. Zesz. Probl Postepow Nauk Rol 535:453-462 [In Polish]

Urban D (2013a) Characteristics of a locality of Hammarbya paludosa (L.) O. Kuntze in the Lęczna-Włodawa Plain (West Polesie). Teka Komis Ochr Środow Przyr 10:448-454

Urban D (2013b) Characteristics of a locality of Liparis loeselii (L.) Rich. on Chełm hills (West Polesie). Teka Komis Ochr Środow Przyr 10:455-461

Urban D. (2007a) Floristic and phytosociological values of peat pits in the area of Komaszyce (the Chodel Basin). Teka Komis Ochr Środow Przyr 4:278-284

Voss EG (1972) Michigan flora. Cranbrook Institute of Science and University of Michigan Herbarium, Detroit, pp 724

Wells TCE, Rothery P, Cox R, Bamford S (1998) Flowering dynamics of Orchis morio (L.) and Herminium monorchis (L.) R. Br. at two sites in eastern England. Bot J Linn Soc 126:39-48 
Wheeler BD, Lambley PW, Geeson J (1998) Liparis loeselii (L.) Rich. in eastern England: constraints on distribution and population development. Bot J Linn Soc 126:141-158

Wilgat T, Michalczyk Z, Turczynski M, Wojciechowski KH (1991) Jeziora łęczyńsko-włodawskie. [Łęczna-Włodawa lakes] Stud Ośr Dok Fizjgr 19[In Polish]

Wołejko L, Pawlaczyk P, Stańko R (eds) (2019) Torfowiska alkaliczne w Polsce - zrożnicowanie, zasoby, ochrona. Wydawnictwo Klubu Przyrodnikow, Świebodzin, pp 315 [In Polish]
Zając A, Zając M (2001) Atlas of distribution of vascular plants in Poland. Institute of Botany, Jagiellonian University, Kraków, 714 pp

Publisher's note Springer Nature remains neutral with regard to jurisdictional claims in published maps and institutional affiliations. 